Dr. sc. Ivan Vukušić: „Odustanak“ kod posebnih kaznenih djela ugrožavanja okoliša Zbornik radova Pravnog fakulteta u Splitu, god. 53, 2/2016., str. 581.-600.

\author{
Dr. sc. Ivan Vukušić1 ${ }^{1}$ poslijedoktorand
}

Pravni fakultet Sveučilišta u Splitu

\title{
„ODUSTANAK“ KOD POSEBNIH KAZNENIH DJELA UGROŽAVANJA OKOLIŠA
}

\author{
UDK: $343: 502 / 504$ \\ Izvorni znanstveni rad \\ Primljeno: 20. 11. 2015.
}

\begin{abstract}
Autor u radu analizira posebna kaznena djela ugrožavanja okoliša. S obzirom na specifičnost i problematiku koja se javlja kod propisivanja kažnjivosti ugrožavanja pravnog dobra, zakonodavac RH je predvidio mogućnost djelotvornog kajanja za neka kaznena djela protiv okoliša. Stoga se analiziraju oblici „odustanka“ koji prema važećem Kaznenom zakonu obuhvaćaju dobrovoljni odustanak i djelotvorno kajanje, a trebali bi obuhvaćati i „nekauzalno djelotvorno kajanje“.
\end{abstract}

Ključne riječi: okoliš, zaštita okoliša, kaznena djela protiv okoliša

\section{UVOD}

Kazneno pravo promovira temeljne društvene vrijednosti ili već postojeće vrijednosti zaštićuje sankcijama. ${ }^{2}$ Objekt kaznenopravne zaštite djela analiziranih u ovom radu jest okoliš u najširem smislu riječi i pri tom se ne misli samo na čovjekov okoliš kojim se neposredno koristi nego i na biološku raznolikost. ${ }^{3}$ Kaznena djela protiv okoliša uređena su u posebnoj glavi kaznenih djela po uzoru na njemačko i austrijsko pravo, ali kaznenih djela protiv okoliša ima i u drugim glavama ${ }^{4}$ posebnog dijela Kaznenog zakona ${ }^{5}$ (dalje u tekstu: KZ). Kada neko ponašanje nije propisano kao kazneno djelo, tada se vodi postupak za naknadu štete tj. građanski postupak, koji je sam po sebi moralno neutralan jer se provodi restitucija počinjenoga. Kazneno pravo uvijek uz kaznenu odgovornost vezuje određeno moralno propitkivanje. ${ }^{6}$ Stoga zakonodavac riskira moralnu osudu ako pravne norme kaznenog prava ne postavi u skladu s moralnim zahtjevima konkretnog društva jer postoji opasnost od proširivanja zone kažnjivosti koja nije

1 Dr. sc. Ivan Vukušić, poslijedoktorand na Katedri za kazneno pravo Pravnog fakulteta u Splitu.

2 Pain, N., Criminal law and environment protection - overview of issues and themes, str. 5., http:// www.aic.gov.au/media_library/publications/proceedings/26/pain.pdf, preuzeto 10. rujna 2015.

3 Novoselec, P. (ur.), Posebni dio kaznenog prava, Zagreb, 2007., str. 267. Kaznena djela protiv okoliša potrebno je razlikovati od kaznenih djela protiv opće sigurnosti jer se prvima primarno štiti okoliš tj. zrak, tlo, tekućine, vode, more itd. dok se kaznenim djelima protiv opće sigurnosti primarno štiti sigurnost ljudi i imovine. Prva kaznena djela su ekološke naravi, dok se druga kaznena djela odnose na sigurnost življenja (VSRH I Kž-300/2011-8).

4 Ibid., str. 268.

5 Kazneni zakon, NN 125/2011, 144/2012, 56/2015, 61/2015.

6 Pain, op. cit., str. 9. 
uvijek dobrodošla. ${ }^{7}$ Pri tom treba uzeti u obzir da kada životinjska i biljna vrsta jednom izumre - nema povratka natrag. ${ }^{8}$

Katalog kaznenih djela protiv okoliša obuhvaća ukupno dvadeset i jedno različito kazneno djelo, uključivo i teška djela protiv okoliša svrstana u posebnu glavu KZ-a. Inkriminacije se mogu raščlaniti imajući u vidu nekoliko kriterija od kojih su najvažniji objekt kaznenopravne zaštite i karakter povrede odnosno ugrožavanja zaštićenog dobra. U radu se analiziraju posebna kaznena djela protiv okoliša koja predstavljaju ugrožavanje. Njih se svrstava u kategoriju posebnih kaznenih djela ugrožavanja jer kažnjavaju stadij koji prethodi onečišćenju te obuhvaćaju specijalne oblike ugrožavanja pa stoga imaju prednost (lex specialis) u odnosu na temeljno kazneno djelo onečišćenja okoliša (čl. 193. KZ-a). ${ }^{9}$ Stoga su u radu analizirane zajedničke značajke „odustanka“ od kaznenih djela ugrožavanja iz važećeg KZ-a kod: Ispuštanja onečišćujućih tvari s plovnog objekta (čl. 194.), Ugrožavanja ozonskog sloja (čl. 195.), Ugrožavanja okoliša otpadom (čl. 196.), Ugrožavanja okoliša postrojenjem (čl. 197.), Ugrožavanja okoliša radioaktivnim tvarima (čl. 198.) i Ugrožavanja bukom, vibracijama ili neionizirajućim zračenjem (čl. 199.).

Sva analizirana kaznena djela u radu su delictum communium što znači da počinitelj može biti svatko. ${ }^{10}$ Ona su također blanketna kaznena djela jer se potpuni zakonski opis može utvrditi jedino ako se uzmu u obzir i drugi propisi izvan KZ-a. Ovo je opravdano ako uzmemo u obzir da se radi o kompleksom području ljudskog života i procesnim odredbama o načinu postupanja s opasnim tvarima koji su regulirani zakonima drugih pravnih grana.

\section{OBLICI KAZNENIH DJELA UGROŽAVANJA}

Neki smatraju kako kazneno pravo u pravilu nije preventivno jer nastupa na scenu tek kada se ostvari neko ponašanje. Pri tom se gubi iz vida da upravo iz tog razloga zakonodavac kažnjava ugrožavanje okoliša, reagirajući odmah s represijom kako ne bi došlo do povrede. ${ }^{11}$

Kaznena djela protiv okoliša se u modernim zakonodavstvima pretežno reguliraju kao kaznena djela ugrožavanja kod kojih se ne traži da dođe do povređivanja zaštićenog pravnog dobra, već je dovoljna i opasnost od njegova povređivanja. Obično se govori o dvije skupine kaznenih djela ugrožavanja: delikti

7 Lazarus, R. J., „Mens Rea in Environmental Criminal Law: Reading Supreme Court Tea Leaves“, Fordham Environmental Law Review, vol. 7, 3/2011., str. 868.

8 Ibid.

9 Cvitanović pod ovom vrstom kaznenih djela razmatra i protupravnu eksploataciju rudnog blaga (čl. 211. KZ-a) i protupravnu gradnju (čl. 212. KZ-a), a zbog specifičnosti tih kaznenih djela koja mogu predstavljati povređivanje, njih se neće analizirati u okviru ovog rada. Novoselec, op. cit., str. 273.

10 I kada Zakon o odgovornosti pravnih osoba za kaznena djela nije bio na snazi, odgovornost pravne osobe utvrđivala se u pravilu prekršajno odnosno za gospodarske prijestupe (VSRH IV Kž-88/01).

11 Pain, op. cit., str. 3. 
konkretnog ugrožavanja i delikti apstraktnog ugrožavanja. ${ }^{12}$ Oni se razlikuju po tome što kod prvih sud mora utvrditi da je došlo do ugrožavanja zaštićenog dobra, tj. do stvarne opasnosti od njegova povređivanja, dok je kod drugih dovoljno da počinitelj ostvari kažnjivu radnju koja je sama po sebi opasna pa se kažnjavanje propisuje i kada nije došlo do povređivanja a ni do konkretne opasnosti.

U austrijskoj i njemačkoj doktrini se, uz navedene dvije kategorije, govori i o prijelaznom obliku kaznenih djela ugrožavanja - tzv. delikti podobnosti (delikti apstraktne podobnosti, delikti potencijalnog ugrožavanja odnosno apstraktnokonkretni delikti). Kod njih radnja iz bića mora biti prikladna za povređivanje zaštićenog pravnog dobra. Riječ je zapravo o podvrsti delikata apstraktnog ugrožavanja jer ni kod njih ne mora nastupiti neposredna ugroženost zaštićenog dobra. Međutim, delikti podobnosti imaju dodirnih točaka s deliktima konkretnog ugrožavanja zato što je i kod jednih i kod drugih opasnost izrijekom navedena u zakonskom opisu. ${ }^{13}$ Apstraktni delikt podobnosti postoji kada se u zakonskom tekstu spominje mogućnost nastupa posljedice (primjerice ,može dovesti do onečišćenja" ili „može ugroziti kakvoću”) ili podobnost radnje za povređivanje (primjerice „podobna je da dovede do štete” ili „pogodna je da prouzroči štetu”). Konkretni delikt podobnosti postoji onda kada zakonski opis navodi da je kaznenim djelom dobro ugroženo (,,i time ugrozi”) ili dovedeno u opasnost (,,i time dovede u opasnost"). ${ }^{14}$

Poteškoće u razlikovanju apstraktnog i konkretnog ugrožavanja s kojima se u nekom predmetu neminovno susreće sud, a kojima je u određenoj mjeri pridonijelo i prijašnje loše zakonsko rješenje koje istu kaznu propisuje za oba oblika ugrožavanja, pokazuje opravdanost nove regulacije kaznenog djela ugrožavanja okoliša otpadom (čl. 196. KZ-a) u važećem KZ-u. U njemu se opravdano napušta razlikovanje apstraktnog i konkretnog ugrožavanja kao dvaju oblika ovog kaznenog djela jer je u nekim slučajevima doista teško utvrditi kada apstraktna opasnost prelazi u konkretnu. Sada je navedeno kazneno djelo delikt podobnosti jer se njime dovodi do apstraktnog ugrožavanja medija okoliša što je najviši stupanj kaznenopravne zasštite s aspekta početka kaznenopravne odgovornosti. ${ }^{15}$

U novom KZ-u propisuje se apstraktno ugrožavanje, i to u svom čistom obliku (bez navođenja opasnosti), kada je riječ o ugrožavanju ozonskog sloja (čl. 195. KZ-a), ugrožavanju okoliša postrojenjem ${ }^{16}$ (čl. 197. KZ-a) i ugrožavanju okoliša

12 Novoselec, op. cit., str. 150-151.

13 Maršavelski, A., „Sudska praksa“, Hrvatski ljetopis za kazneno pravo i praksu, Zagreb, vol. 18, 1/2011., str. 292-293.

14 Ibid.; To je slučaj kod kaznenog djela ugrožavanja bukom, vibracijama ili neionizirajućim zračenjem. Turković, K. (ur.), Komentar Kaznenog zakona, Zagreb, 2013., str. 271.

15 Maršavelski, Ibid.; Ovo je kazneno djelo počinio vlasnik i direktor mljekare koji nije ishodio dozvolu za ispuštanje vode s promjenjivim svojstvima unatoč rješenju inspekcije o zabrani ispuštanja otpadnih voda u jarak (Žup. sud u Bjelovaru Kž-340/02), prema: Garačić, A., Kazneni zakon u sudskoj praksi - Posebni dio, Zagreb, 2009.

16 Turković, op. cit., str. 269. 
radioaktivnim tvarima ${ }^{17}$ (čl. 198. KZ-a). Poseban je slučaj kazneno djelo ispuštanja onečišćujućih tvari s plovnog objekta (čl. 194. KZ-a) gdje je također propisano apstraktno ugrožavanje. Kod njega je dovoljno poduzimanje radnje kojom se pogoršava kvaliteta vode bez obzira na to je li takva radnja podobna za ugrožavanje biljnog i životinjskog svijeta ili pak ljudi. Iako nastupanje posljedice predstavlja povređivanje, ono je u drugom planu jer je dovoljno svako pogoršanje kakvoće vode pa makar i za 1 promil. Ovdje je zakonodavac vodio brigu o činjenici da jednom kada je voda onečišćena postoji slaba mogućnost čišćenja. ${ }^{18}$ Konstrukcija delikata apstraktnog ugrožavanja specifična je s obzirom na to da u prvom planu nije odnos radnje prema zaštićenom objektu već prema zaštićenom dobru pa se, unatoč povređivanju objekta, neće raditi o kaznenom djelu povređivanja. ${ }^{19}$

Jedino posebno kazneno djelo protiv okoliša koje predstavlja kažnjavanje konkretnog ugrožavanja jest ugrožavanje bukom, vibracijama ili neionizirajućim zračenjem (čl. 199. KZ-a).

\section{AKCESORNOST}

Težište zaštite okoliša u ranijim je vremenima bilo na prekršajnom i financijskom području. Naime, kaznenim pravom štite se samo fragmenti u smislu najznačajnijih vrijednosti okoliša i to u odnosu na najpogibeljnije oblike ugrožavanja okoliša. ${ }^{20}$ Iz ovih značajki proizlazi i akcesornost kaznenopravne zaštite okoliša jer pravo okoliša obuhvaća desetke zakona i nekoliko stotina podzakonskih propisa na koje izravno (tzv. blanketne dispozicije) ili neizravno upućuju inkriminacije kaznenog prava.

Blanketna su kaznena djela u ovoj oblasti prava poželjna i kao takva ne stvaraju mnoštvo problema. Problem je jedino kada se neki pojam kaznenog prava okoliša shvaća drugačije nego je to slučaj s upravnim pravom. ${ }^{21} \mathrm{U}$ njemačkoj se literaturi stoga spominju blanketna kaznena djela i upravna akcesornost. ${ }^{22}$ Stoga je normu kaznenog prava potrebno povezati s normama upravnog prava jer, da bi se došlo do ispravnog tumačenja bića kaznenog djela, potrebno je uzeti u obzir sustavno

17 Ibid., str. 271.

18 Ibid., str. 266.

19 Novoselec, op. cit., str. 274.

20 Ibid., str. 269; VSRH I Kž-49/2011-4 utvrdio je da nije dovoljno samo kvalificiranje prekršajnog postupka kao „kaznenog“ u smislu Europske konvencije za zaštitu ljudskih prava i temeljnih sloboda po pitanju načela ne bis in idem, pozivajući se na kriterije koji su proklamirani presudom Maresti i ostalom praksom Europskog suda za ljudska prava, nego ih treba obrazloženo primijeniti na konkretni slučaj.

21 Busch, R. - Iburg, U., Umweltstrafrecht, Berlin, 2002., str. 62.

22 Ibid., str. 29; Isto Bačić, F. - Pavlović, Š., Komentar Kaznenog zakona, Zagreb, 2004., str. 882. 
tumačenje i povezati ga s normama drugih grana prava. ${ }^{23}$ Pri tom se ne smije zanemariti ni mogućnost primjene Konvencija koje uređuju ovu materiju.

Naime, ako zakonski opis kaznenog djela upućuje na primjenu nekog drugog pravnog propisa, tada se radi o blanketnom kaznenom djelu, pa čak i u slučaju kada se ne koristi ustaljeni pojam ,tko protivno propisima“ nego i ako se primjerice koristi pojam ,neovlašteno“ koji se u određenim slučajevima može tumačiti kroz blanketnost i druge propise. Ako KZ koristi neke pojmove čija se definicija nalazi u drugim propisima druge grane prava, ali zakonski opis kaznenog djela u KZ-u ne upućuje na drugi propis, u tom slučaju je potrebno uzeti tumačenje spornog pojma iz druge grane prava zbog jedinstva pravnog poretka. Ako neki pojam kaznenopravno treba shvatiti drugačije nego to pravni propis druge grane prava definira, tada taj pojam treba zakonskim definicijama u KZ-u izričito apostrofirati. ${ }^{24}$

Tumačenje je u kaznenom pravu uvijek dopušteno ako je u korist počinitelja. Ali ono je ograničeno riječima i značenjem izraza koji su korišteni. Ako se tumačenjem izlazi iz okvira riječi i izraza koje je zakonodavac koristio, tada se radi o nedopuštenoj analogiji. ${ }^{25}$

Postoji jedna specifičnost kod ovih kaznenih djela, a u pravilu se odnosi na pitanje je li određena radnja kažnjiva u slučaju zablude koja ne vodi automatski do nekažnjivosti. Dapače, postoji puna kažnjivost kada je zabluda otklonjiva, odnosno kada počinitelj nije bio upoznat sa sadržajem propisa koji pripadaju području druge grane prava iako je on bio dužan ${ }^{26}$ Stoga se može zaključiti da je kod kaznenih djela protiv okoliša potrebno promatrati odredbe općeg dijela KZ-a o zabludi kao i kod svih drugih kaznenih djela.

\section{POKUŠAJ}

Pokušaj, prema čl. 34. KZ-a, postoji kada počinitelj s namjerom poduzme radnju koja vremenski i prostorno neposredno prethodi ostvarenju bića kaznenog djela. Pokušaj je kažnjiv kod kaznenih djela kod kojih se može izreći kazna zatvora od pet godina ili teža ili ako je pokušaj izričito propisan kao kažnjiv. ${ }^{27}$

23 Oliver Hanzler, prikaz: Martin, Julia A.: „Sonderdelikte im Umweltstrafrecht“, 2006. u Natur und Recht, vol. 28, 7/2006., str. 425-426. U ovom radu spominje se i upitnost kažnjavanja voditelja poduzeća ako radnik bez njegovog dopuštenja počini neku radnju, tj. neovlašteno, čime se zadire u tematiku odgovornosti pravnih osoba za kaznena djela. V. više u Sokanović, L., „Die strafrechtliche Verantwortlichkeit der juristischen Personen im Lichte des neuen kroatischen Umweltstrafrects“, Zbornik radova Pravnog fakulteta u Splitu, vol. 50, 4/2013., str. 977-990.

24 Busch - Iburg, op. cit., str. 29.

25 Ibid., str. 23; O vrstama analogije u kaznenom pravu i situaciji kada je ona dopuštena v. Kurtović Mišić, A. - Krstulović Dragičević, A., Kazneno pravo (Temeljni pojmovi i instituti), Split, 2014., str. 7273.

26 Reindl, S., Österreichisches Umweltstrafrecht, Wien, 2006., str. 6.

27 Prethodno je spomenut okvir kazne, no sud se pri odmjeravanju i izricanju kazne neće samo voditi počinjenim nego i eventualno drugim kaznenim djelima. Naime, VSRH I Kž-611/2014-4 utvrdio je kako okolnost da je počinjeno kazneno djelo za vrijeme roka provjeravanja iz uvjetne osude upućuje na recidiv. Činjenica da je zatvorenik kazneno djelo počinio u vrijeme roka provjeravanja određenog 
Među analiziranim kaznenim djelima u radu to su čl. 196. st. 2., 197. st. 1., 198. st. 1. KZ-a.

Pokušaj podrazumijeva da je subjektivna strana počinjenja u potpunosti ostvarena dok je objektivna strana neispunjena. Sudovi su se složili da počinitelj mora biti svjestan da povređuje životinju, a ne treba biti svjestan o kojoj vrsti životinje se radi pa je ista situacija i kod okoliša. Tomu je tako osim ako pravna odredba ne propisuje posebnu kažnjivost osobe koja zna da se radi o posebnom segmentu okoliša koji je ugrožen. ${ }^{28}$ Navedeno se razmatra kroz element pokušaja koji se naziva namjera na obilježja kaznenog djela.

S obzirom na to da je kod pokušaja uz namjeru potrebno utvrditi i neposrednost, neposrednost ostvarenja bića kaznenog djela se najpreciznije utvrđuje primjenom kriterija plana počinitelja. Time je definicijom pokušaja u RH proklamirana individualno-objektivna teorija. Primjerice, kupnja pumpe za ispuštanje otrova u rijeku nije pokušaj, ali vremenski i prostorno neposredna radnja paljenja pumpe jest. Pri tom se ne smije zanemariti ni materijalno-objektivna teorija koja neposrednost kod pokušaja promatra kroz prirodno jedinstvo između poduzete radnje i radnje iz bića kaznenog djela. Ova teorija neposrednost utvrđuje s aspekta prirodnog jedinstva kada plan počinitelja nije poznat. ${ }^{29}$

Pripremne radnje u pravilu kaznenim pravom nisu kažnjive jer se kažnjivost ustanovljava tek s početkom neposredne opasnosti ostvarenja bića kaznenog djela. ${ }^{30}$ Cinjenica da je pokušaj rijetko kažnjiv kod ovih kaznenih djela opravdana je jer on podrazumijeva pomicanje zone kažnjivosti prema naprijed. Unatoč pomicanju zone kažnjivosti u prethodni stadij, zakonodavac omogućava blaže kažnjavanje počinitelja kod instituta pokušaja. ${ }^{31}$ Budući da analizirana kaznena djela ugrožavanja okoliša kažnjavaju i pripremne radnje, onda nema potrebe za kažnjavanjem kasnijeg stadija, tj. pokušaja.

Većina pripremnih radnji kaznenih djela protiv okoliša kvalificirane su u KZ-u kao dovršeno kazneno djelo. Iz tog razloga je zakonodavac predvidio djelotvorno

mu ranijom uvjetnom osudom, iako je ona opozvana pa je zatvoreniku bila izrečena jedinstvena kazna zatvora, predstavlja, suprotno žalbenim tvrdnjama zatvorenika, važnu okolnost za odlučivanje o uvjetnom otpustu i ocjenu hoće li njegova primjena odvratiti zatvorenika od činjenja kaznenih djela.

28 Lazarus, op. cit., str. 878. I Žup. sud u Varaždinu (Kž-681/11) napominje kako je uvijek potrebno utvrditi namjeru počinitelja, a ne se zadovoljiti samo s utvrđenom radnjom, jer, primjerice, počinitelj može „kamen koji je iskopao na svojim oranicama, razvoziti po poljskim putevima i time zapravo napraviti korist drugima, a ne sebi pa onda nije postupao s namjerom da stekne nepripadnu imovinsku korist“ sukladno čl. 261.a Kaznenog zakona, NN 110/1997, 27/1998, 50/2000, 129/2000, 84/2005, 51/2001, 111/2003, 190/2003, 105/2004, 71/2006, 110/2007, 152/2008, 57/2011, 77/2011, 125/2011, 143/2012 (dalje u tekstu: KZ/97).

29 VSRH IV Kž-72/2010-7 naglašava važnost odredbi Općeg dijela KZ-a jer daje „drugu šansu“ prvostupanjskom sudu za nepostojanje čl. 261.a st. 3. KZ/97 kada je u postupku utvrđeno da su optuženici nastavili s izvođenjem radova nakon što im je istekla koncesija, ali da je postupak odobravanja nove koncesije bio spor, pa da nisu mogli zastati s radom, pri čemu prvostupanjski sud propušta navesti okolnosti na temelju kojih je izveo zaključak da nastavak radova bez koncesije ne predstavlja ostvarenje objektivnog učina inkriminiranog kaznenog djela.

30 Busch - Iburg, op. cit., str. 37.

31 Ibid., str. 36. 
kajanje kod ovih kaznenih djela jer dobrovoljni odustanak od dovršenog kaznenog djela nije moguć. Tako radnje uvoza i izvoza koje su po svojoj pravnoj konstrukciji pripremne nalazimo kod ugrožavanja ozonskog sloja (čl. 195. KZ-a), ugrožavanja okoliša otpadom (čl. 196. KZ-a) i ugrožavanja okoliša radioaktivnim tvarima (čl. 198. KZ-a). ${ }^{32}$

Pravo okoliša poznaje i minimalnu klauzulu koja postoji kada je ostvarena zanemariva šteta, a biće kaznenog djela zahtijeva ostvarenje znatne štete. ${ }^{33}$

\subsection{Pokušaj i nehaj}

Sva kaznena djela su kažnjiva ako se postupa s namjerom, ali KZ propisuje kažnjivost kaznenih djela protiv okoliša s nehajem, pa se postavlja pitanje opravdanosti ne/kažnjivosti pokušaja kaznenog djela s tim oblikom krivnje.

Na pitanje zašto je stupanj krivnje nizak kod kaznenih djela protiv okoliša, odgovor polazi od činjenice da se radi o kaznenim djelima ugrožavanja, ali i iz razloga što je lakše dokazati niži nego viši stupanj krivnje. ${ }^{34} \mathrm{Od}$ analiziranih kaznenih djela u ovom radu se sva mogu počiniti s nehajem, s iznimkom čl. 199. KZ-a koji može biti počinjen samo s namjerom jer počinitelj mora imati svijest o buci/vibracijama pa je nehaj teško zamisliv. Iako je kažnjiv nehaj kod ugrožavanja okoliša otpadom, ugrožavanja okoliša postrojenjem i ugrožavanja okoliša radioaktivnim tvarima, jasno je da se ne mogu pokušati oni stavci koji kažnjavaju nehaj i to ne samo zbog propisanog blažeg kaznenog okvira, nego i zbog činjenice da pokušaj podrazumijeva isključivo postupanje s namjerom.

Ishod nehajnog ponašanja je cijena koju je počinitelj spreman platiti stvaranjem rizika. ${ }^{35}$ Ipak je ispravan zaključak kako pokušaj podrazumijeva namjeru da se nešto učini, a ne može se pokušati nešto učiniti ako ne namjeravaš to učiniti. Drugim riječima, ako namjera osobe nije usmjerena na neku posljedicu, ne može se reći da je osoba nešto pokušala. ${ }^{36}$ Nesvrhovito stvaranje kaznenog rizika ne može se nazvati pokušajem. Namjera da nastupi nenamjeravana posljedica logički je neodrživa. Ako počinitelj hoće/pristaje da nastupi posljedica, takva posljedica ne može biti rezultat nenamjere. ${ }^{37}$ Kod nehajnih kaznenih djela pokušaj nije kažnjiv, iako je on načelno zamisliv, posebno kod svjesnog nehaja zbog

32 Ibid., str. 37.

33 U pravu RH minimalna klauzula je priznata člancima kod primjerice uništavanja zaštićene prirodne vrijednosti (čl. 200., st. 3. KZ-a) i trgovanja zaštićenom prirodnom vrijednosti (čl. 202., st. 3. KZ-a). Nema kaznenog djela ako je počinjeno prema neznatnoj količini pripadnika svojte ili druge zaštićene prirodne vrijednosti i neznatno je utjecalo na očuvanje te svojte ili druge zaštićene prirodne vrijednosti. Ovo rješenje je logično jer se minimalna klauzula primjenjuje na neznatno povređivanje a ne ugrožavanje.

34 Lazarus, op. cit., str. 873.

35 Enker, A. N., „Mens rea and criminal attempt“, American Bar Foundation Research Journal, 4/1977., str. 856 .

36 Chiao, prema: Vukušić, I., Razgraničenje pripremnih radnji i pokušaja u teoriji i sudskoj praksi, Zagreb, 2014., str. 163.

37 Giese, D., Zur Abgrenzung von Vorbereitung und Versuch, Frankfurt a.M., 1961., str. 19. 
intelektualne sastavnice koja je jednaka kao kod neizravne namjere. ${ }^{38}$ Ako osoba ne onečisti okoliš otpadom i ako osoba barem ne pristaje na onečišćenje okoliša otpadom, tada postoji pokušaj iz nehaja ako postoji neposredno započinjanje. ${ }^{39}$ Često se kod svjesnog nehaja radije govori o virtualnoj sigurnosti nego o visokom stupnju vjerojatnosti, istodobno očekujući da povećana krivnja rezultira povećanim povređivanjem čime se aritmetički gleda na ovu problematiku jer je pokušaj kažnjiv, u pravilu, kod težih kaznenih djela. Ali jasno je kako ovo nije točno. Dolazimo do zaključka kako ove dvije vrijednosti nisu aritmetički povezane, te aritmetičkom modelu ne treba pokloniti puno pažnje. Naime, nehaj se može smatrati opasnim kao i namjera. Također trebamo uzeti u obzir činjenicu da se počinitelj pri počinjenju kaznenog djela susreće s mnoštvom prepreka koje mora prijeći, a da nema namjere, te prepreke ne bi pokušao prijeći. Činjenica je da generalno možemo vjerovati da će ljudi učiniti ono što namjeravaju, ali ne možemo računati na to da će ljudi počiniti nešto što ne vjeruju da će učiniti. ${ }^{40}$

Sljedeći problem do kojeg dolazimo odnosi se na pitanje zašto bi element krivnje kod pokušaja bio stroži, nego je to slučaj kod dovršenog kaznenog djela.

Šira interpretacija oblika krivnje kod pokušaja (kažnjavanje pokušaja iz nehaja i da je nehaj teorijski zamisliv) predstavljala bi prekomjerno i bezrazložno proširenje zone kažnjivosti. Tada bi došlo do povećane prevencije kriminaliteta te bi mnogo građana potpalo pod odgovornost u kaznenom smislu, a takav ishod ne bi donio pozitivne posljedice. I naš zakonodavac načelno propisuje kažnjavanje pokušaja kod kaznenih djela kod kojih je propisana kazna zatvora od pet godina. To su, u pravilu, teža kaznena djela koja podrazumijevaju namjeru kao oblik krivnje pa je vidljivo da i on želi suziti zonu kažnjivosti pokušaja, što treba i odobriti jer bi već propisivanje kažnjavanja pokušaja s nižim oblikom krivnje stopiralo neke korisne aktivnosti. Takva zakonska regulacija ne bi dovela do pozitivnih posljedica.

Stoga sud treba utvrditi da je počinitelj bio svjestan činjenica koje sačinjavaju i tvore kazneno djelo da bi se utvrdila namjera kod pokušaja. ${ }^{41}$

\section{DOBROVOLJNI ODUSTANAK}

Prvi tragovi instituta dobrovoljnog odustanka datiraju još iz rimskog prava. ${ }^{42}$ Ako bi počinitelj dobrovoljno odustao od počinjenja kaznenog djela, kod određenih kaznenih djela, bilo je predviđeno oslobođenje od kazne. Te situacije, međutim,

38 Eser, u: Schönke, A. - Schröder, H., Strafgesetzbuch Kommentar, Beck-online, 2010., § 22, II. 22.; Tako je odredio i Sturm i Wolter, prema: Guhra, E., Das vorsätzlich-tatbestandsmäßige Verhalten beim beendeten Versuch, Berlin, 2002., str. 46.

39 Postavlja se pitanje je li država ipak odlučila kažnjavati pokušaj s nehajem kriminalizirajući ugrožavanje. Chiao, Duff, prema: Vukušić, I., op. cit., str. 163.

40 Yaffe, G., Attempts, Oxford, 2010., str. 56.

41 Lazarus, op. cit., str. 873.

42 Vuletić, I., Teoretsko opravdanje, pravna priroda i pravni učinak dragovoljnog odustanka od pokušaja u hrvatskom kaznenom pravu, Zagreb, 2011., str. 71. 
nisu uživale pretjerani značaj s obzirom na to da je u rimskom pravu vrijedilo opće pravilo kako je nedovršeni delikt načelno nekažnjiv. Zbog toga nije bilo potrebe za razvijanjem općeg instituta dobrovoljnog odustanka ili djelotvornog kajanja. ${ }^{43}$ Razvoj odustanka kao općeg instituta počinje tek s glosatorima i postglosatorima. ${ }^{44}$ Oni su uobličili opći pojam pokušaja ${ }^{45}$ te, nasuprot njemu, uspostavili dobrovoljni odustanak koji je počinitelju donosio nekažnjivost.

U čl. 35. KZ-a predviđen je dobrovoljni odustanak od pokušaja tj. tada kada djelo još nije ni formalno dovršeno. Da bi se utvrdio način dobrovoljnog odustanka, potrebno je analizirati radi li se o dovršenom pokušaju kada je potrebno aktivno sprečavanje posljedice ili je riječ o nedovršenom pokušaju kada je potrebna pasivnost počinitelja. Razlikovanje dovršenog i nedovršenog pokušaja najbolje se ocrtava kod momentalnih i temporalnih delikata. Kod momentalnih kaznenih djela posljedica nastupa odmah nakon dovršetka radnje počinjenja pa dobrovoljni odustanak nije moguć. ${ }^{46}$ Ako posljedica nastupa protekom određenog vremena nakon dovršetka radnje počinjenja, takva se kaznena djela nazivaju temporalnim deliktima te je kod njih dobrovoljni odustanak moguć i nakon dovršenog pokušaja. Važnost je dobrovoljnog odustanka u učinku koji predviđa KZ, a predstavlja fakultativno oslobođenje od kazne. ${ }^{47}$

S obzirom na to da kazneno djelo ne smije biti formalno dovršeno da bi se primijenio dobrovoljni odustanak, potrebno je razlikovati dovršenje kaznenog djela u smislu ostvarenja bića kaznenog djela (formalno dovršenje) i povređivanja pravnog dobra (materijalno dovršenje) jer nakon formalnog dovršenja kaznenog djela počinitelj može ostvarivati kvalificirana obilježja, a postoji i mogućnost uključivanja drugih dionika u počinjenje kaznenog djela. ${ }^{48}$ Djelo je dovršeno u formalnom smislu kada su se ostvarila sva njegova obilježja i formalno je dovršenje u načelu dovoljno da se kazneno djelo smatra dovršenim..$^{49}$ Razlikovanje formalnog i materijalnog dovršenja dolazi u obzir kod kaznenih djela kod kojih počinitelj postupa s određenim ciljem, i kako je spomenuto, u slučajevima kada počinitelj $\mathrm{i}$ nakon formalnog dovršenja nastavlja s ostvarivanjem kaznenog djela. ${ }^{50}$ Postoji li vremenski interval između formalnog i materijalnog dovršenja, tj. naknadna zona djelovanja, potrebno je procijeniti s aspekta strukture kaznenog djela, oblika radnje počinjenja, kao i s aspekta smisla i cilja pojma materijalnog

43 Müller, M. P., Die geschichtliche Entwicklung des Rücktritts vom Versuch bis zum Inkrafttreten des neuen STGB - AT 1975, Europäische Hochschulschriften, Frankfurt am Main - Berlin - Bern - New York - Paris - Wien, 1995., str. 22-28.

44 Vuletić, op. cit., str. 71.

45 V. više o povijesnom razvoju instituta pokušaja u Vukušić, op. cit.

46 Kurtović Mišić - Krstulović Dragičević, op. cit., str. 154-155.

47 Ibid.

48 Wessels, J. - Beulke, W., Strafrecht-Allgemeiner Teil, Passau, 2010., str. 221.

49 Kurtović Mišić - Krstulović Dragičević, op. cit., str. 106.

50 Ibid. 
dovršenja što je upravo slučaj s trajnim kaznenim djelima i kaznenim djelima koja u biću imaju anticipirano dovršenje kaznenog djela. ${ }^{51}$

Kažnjavanje ranijeg stadija (formalno dovršenje) ne znači kako kasniji stadij u počinjenju koji se odnosi na ponašanje tipično za biće kaznenog djela i realiziranje oštećenja pravnog dobra (materijalno dovršenje) neće biti adekvatno kažnjeno. ${ }^{52}$ Prijetnja kaznom uvijek se odnosi na cjelokupni tijek počinjenja kaznenog djela. Činjenica je da ponekad biće kaznenog djela predviđa dostatnim ostvarenje jedne radnje da bi odmah došlo do materijalnog dovršenja (k.d. stanja, momentalna kaznena djela), ali materijalno dovršenje ne treba prerestriktivno shvaćati jer ono ne treba biti opisano u biću kaznenog djela. Do njega se može doći i samim tumačenjem. Potrebno je u zakonskoj normi uočiti materijalni smisao zabrane u smislu bića i nepravo koje je bićem kaznenog djela predstavljeno. ${ }^{53}$

Upitno je je li moguć dobrovoljni odustanak kada je počinitelj poduzeo radnju i već time postigao cilj, a nije nastupilo dovršenje. Odnosno, je li počinitelj odustao od pokušaja kaznenog djela jer je počinio sve što je planirao učiniti.

Roxin, Puppe i Schall smatraju kako je dobrovoljni odustanak ovdje isključen kada je počinitelj ostvario svoj cilj koji još nije obuhvaćen bićem kaznenog djela (aussertatbestandliches Ziel).$^{54}$ Suprotno stajalište polazi od činjenice da je počinitelj ostvario svoj cilj pa mu se omogućava dobrovoljni odustanak i tako se osigurava nekažnjivost. Prema tom suprotnom stajalištu, počinitelj bi mogao pravno dobro povrijediti i više kada zna da neće biti kažnjen, pa se postavlja pitanje je li žrtva u dovoljnoj mjeri zaštićena. ${ }^{55}$ Ovu problematiku povlačenja počinitelja koji je poduzetom radnjom ostvario svoj cilj potrebno je razmatrati s aspekta stadija počinjenja koji je ostvaren.

Vladajuće mišljenje ipak polazi od činjenice da okolnost što je počinitelj ostvario svoj cilj koji još nije obuhvaćen bićem dovršenog kaznenog djela nema učinka na sposobnost dobrovoljnog odustanka od pokušaja. ${ }^{56}$ Ovdje se radi o dovršenom pokušaju i da bi se počinitelju priznao dobrovoljni odustanak, potrebno je da poduzme aktivnu radnju što on nije poduzeo. Nema odnosa počinitelja prema kaznenom djelu zbog kojeg bi zaslužio oslobođenje od kazne s obzirom na to da je ostvario sve što je namjeravao.

Zakonska odredba dobrovoljnog odustanka iscrpljuje se zahtijevanjem određenog izvanjskog ponašanja na temelju objektivne radnje. Postoji li dobrovoljnost u konkretnom slučaju jest drugo pitanje koje treba odvojeno razmotriti. Ipak je dobrovoljnost psihološki pojam a ne moralni, a vrednovanje

${ }^{51}$ Wessels - Beulke, op. cit., str. 221.

52 Ibid

53 Ibid.

${ }_{54}$ Hefendehl, R., https://strafrecht-online.org/lehre/ws-2014/strafrecht-at/\%C2\%A7\%2024\%20 -\%20R\%C3\%BCcktritt\%20vom\%20Versuch\%20und\%20t\%C3\%A4tige\%20Reue $\% 20$ KK $\% 20443-462$. pdf, preuzeto 1. rujna 2015., str. 454.

55 Ibid.

56 Ibid. 
motiva igra ulogu pri odmjeravanju kazne, osobito kod pitanja hoće li se počinitelja osloboditi kazne pa će počinitelj koji je odustao iz moralnih motiva zasigurno imati više izgleda na oslobođenje od kazne. ${ }^{57}$

Treba razlikovati dobrovoljni odustanak od djelotvornog kajanja koje je uglavnom predviđeno kod kaznenih djela apstraktnog ugrožavanja. Stoga se dobrovoljni odustanak i djelotvorno kajanje razlikuju u činjenici što je dobrovoljni odustanak onemogućen kada je kazneno djelo formalno dovršeno dok je djelotvorno kajanje moguće tek nakon formalnog dovršenja kaznenog djela. Stoga je djelotvorno kajanje moguće samo kod materijalnih djela s posljedicom a ne kod formalnih kaznenih djela. ${ }^{58}$ Isključen je dobrovoljni odustanak i djelotvorno kajanje uvijek kada počinitelj smatra da s postojećim sredstvima neće moći ostvariti kazneno djelo. ${ }^{59}$

\section{DJELOTVORNO KAJANJE}

Djelotvorno kajanje postoji kada počinitelj nakon formalnog dovršenja spriječi materijalno dovršenje ili pokuša ${ }^{60}$ spriječiti/otkloniti posljedice djela. Pokušaj sprečavanja materijalnog dovršenja može se pojaviti u dva oblika. Prvi se odnosi na situaciju kada kazneno djelo ne bude materijalno dovršeno neovisno o radnji počinitelja (,nekauzalno djelotvorno kajanje“). Drugi oblik se odnosi na situaciju kada kazneno djelo, unatoč pokušaju sprečavanja materijalnog dovršenja, ipak bude dovršeno. Kajanje nije primjeren izraz jer se ne traži moralna motivacija iako je u dosadašnjoj literaturi prevladavao termin „stvarno kajanje“ pa se uporabom „stvarno“ hoće naglasiti da nije dovoljno verbalno izražavanje „kajanja“ nego se traži očitovanje u počiniteljevoj djelatnosti, u njegovom činu. ${ }^{11} \mathrm{KZ} / 97$ je kod nekih kaznenih djela za djelotvorno kajanje propisivao i obvezno oslobođenje od kazne, ali je važeći KZ predvidio fakultativno oslobođenje od kazne kod svih kaznenih djela s mogućnošću djelotvornog kajanja. ${ }^{62}$

U glavi kaznenih djela protiv okoliša zakonodavac je predvidio djelotvorno kajanje u čl. 213. KZ-a jer sud može osloboditi kazne počinitelja kaznenog djela iz čl. 193., čl. 194., čl. 196., čl. 197. te čl. 198. KZ-a koji prije nastupa

57 Novoselec, P., Opći dio kaznenog prava, Zagreb, 2009., str. 314.

58 Kottmann, R., Die abgrenzung des Rücktritts von der tätigen Reue nach Art. 23 StGB, Luzern, 2010., str. 5.

59 Ibid., str. 3.; Hefendehl, op. cit., str. 444.

60 Kurtović Mišić - Krstulović Dragičević, op. cit., str. 154; KZ kod djelotvornog kajanja pojedinih kaznenih djela zahtijeva da je spriječeno materijalno dovršenje kaznenog djela, a nije dovoljan pokušaj sprečavanja materijalnog dovršenja. KZ ipak u čl. 102. terorističko udruženje i u čl. 328. zločinačko udruženje zahtijeva sprečavanje posljedice od počinitelja, ali podredno dopušta primjenu djelotvornog kajanja na pripadnika udruženja ako se otkrije udruženje prije nego je u njegovu sastavu ili za njega počinjeno kazneno djelo. Time se članu udruženja priznaje djelotvorno kajanje. Rizik sprečavanja materijalnog dovršenja kaznenog djela KZ prebacuje na nadležna tijela kojima je otkrivanje udruženja prijavljeno.

${ }_{61}$ Novoselec, P. - Bojanić, I., Opći dio kaznenog prava, Zagreb, 2013., str. 316.

62 Ibid. 
teških posljedica dobrovoljno otkloni opasnost ili stanje koje je prouzročio. Ovdje zakonodavac zahtijeva sprečavanje materijalnog dovršenja tako da pokušaj sprečavanja materijalnog dovršenja ne proizvodi pravne učinke u smislu djelotvornog kajanja. Prema važećem tekstu KZ-a, djelotvorno je kajanje moguće primijeniti i na kaznena djela protiv okoliša koja se čine s nehajem jer čl. 213. KZ-a nije ograničio svoju primjenu samo na stavke koji obuhvaćaju namjeru nego se referirao na cijele članke odgovarajućih kaznenih djela protiv okoliša.

Uzimajući u obzir pravnu prirodu posebnih kaznenih djela protiv okoliša koja se u radu analiziraju i ona kaznena djela kod kojih je predviđeno djelotvorno kajanje, prema Komentaru KZ-a radne skupine, proizlazi da je ono predviđeno samo kod kaznenih djela apstraktnog ugrožavanja. Tu postoji vremenski interval između ugrožavanja i povređivanja, odnosno nastupa teških posljedica pa je onda i zakonodavac omogućio počinitelju djelotvorno kajanje u tom vremenu. Dobrovoljni je odustanak relativno sigurno sredstvo za sprečavanje dovršenja dok je djelotvorno kajanje po prirodi rizična radnja jer je djelo već formalno dovršeno. Stoga je potrebno razmotriti elemente djelotvornog kajanja: ${ }^{63}$

a) Mora postojati kazneno djelo kod kojeg je moguće djelotvorno kajanje (reuefahige Straftat). Djelotvorno kajanje je moguće samo kod onog kaznenog djela gdje ga KZ izričito propisuje a pri tom se ne gleda priroda tog kaznenog djela. ${ }^{64}$ Iako je djelotvorno kajanje uvijek predviđeno kod sličnih kaznenih djela ugrožavanja, ako za pojedino kazneno djelo nije izričito propisana mogućnost djelotvornog kajanja, tada pravna analogija nije dopuštena unatoč činjenici da postoji slično kazneno djelo ugožavanja za koje je već predviđeno djelotvorno kajanje.

b) Materijalno dovršenje (šteta) mora biti u cijelosti spriječeno (otklonjena). KZ kod kaznenih djela protiv okoliša zahtijeva uklanjanje stanja koje je počinitelj prouzročio tako da ne nastupe teške posljedice jer upravo one predstavljaju materijalno dovršenje kaznenog djela nakon čega nije moguće djelotvorno kajanje. Cilj djelotvornog kajanja treba biti potpuno uklanjanje štete. Pri tom je dovoljno da je nominalna šteta uklonjenja, primjerice, nije potrebno da su naknađene i kamate na koje je žrtva imala pravo. Načelno, počinitelj mora osobno poduzeti radnju djelotvornog kajanja što zahtijeva i čl. 213. KZ-a. Iznimno se može odobriti i radnja djelotvornog kajanja putem trećeg, ali u svoje ime (primjerice poduzeća). Smatra se da je šteta istodobno otklonjena ako se počinitelj ugovorno obveže u cijelosti naknaditi štetu u određenom roku. U tom slučaju djelotvorno kajanje proizvodi učinak (nastaje) tek u slučaju kada šteta bude u potpunosti sanirana. ${ }^{65}$

c) Pravovremena radnja (rechtzeitige Handlung). Djelotvorno kajanje mora uslijediti pravovremeno što znači da je materijalno dovršenje spriječeno ili postoji sporazum za sprečavanje materijalnog dovršenja do kojeg je neminovno

63 Reindl, op. cit., str. 6.

64 http://www.jus24.at/a/rechtsfolge-der-t\%C3\%A4tigen-reue, preuzeto 10. rujna 2015.

${ }_{65}$ Ibid.; Uvijek je potrebno vidjeti što kaznene odredbe zahtijevaju, sprečavanje materijalnog dovršenja ili pokušaj sprečavanja materijalnog dovršenja. 
trebalo doći prije nego je nadležno tijelo saznalo za krivnju počinitelja. Radnja djelotvornog kajanja nije pravovremena ako postoji sumnja nadležnih tijela o identitetu počinitelja ili ako kod državnog odvjetništva postoji prijava. Nadležnim tijelom smatraju se državno odvjetništvo, sud, ali i javni organi kao policija i policijski službenici. ${ }^{66}$

d) Dobrovoljnost (Freiwiligkeit). Dobrovoljnost podrazumijeva poduzimanje radnje djelotvornog kajanja bez prisile. To je situacija kada postoji autonomna odluka, tj. slobodna odluka na temelju savjesti, kajanja, suosjećanja ili općenito strah od kazne koja nije utemeljena na opasnosti od otkrivanja. ${ }^{67}$

Nedobrovoljna je odluka koja se temelji na heteronomnom temelju. To će biti primjerice susret s policajcem ili predodžba da je kazneno djelo već otkriveno. To je situacija kada bi materijalno dovršenje možda i bilo moguće, ali bi bilo skopčano s neugodnostima ili vezano uz rizike na koje počinitelj nije računao ${ }^{68}$ Stoga ne smije postojati izvanjska prisila koja onemogućava da se nastavi s kaznenim djelom jer tada nema dobrovoljnosti. Nema dobrovoljnosti ${ }^{69}$ ako je sa stajališta počinitelja bilo razumno pobjeći, kao primjerice, ako počinitelj izbjegava nalog za pretragu pa nadokadi štetu kako bi izbjegao pronalazak stvari koja se nalazi u njegovom posjedu, ili kada preda stvar jer je zatečen u počinjenju kaznenog djela. ${ }^{70}$ Iako je radnja djelotvornog kajanja poduzeta, zbog nepostojanja dobrovoljnosti ne proizvodi pravne učinke. ${ }^{71}$

\subsection{Pravne posljedice djelotvornog kajanja}

Ako popravak prouzročenog stanja nastupi pravodobno, dobrovoljno i potpuno, tada djelotvorno kajanje otklanja nastupanje posljedice kaznenog djela. ${ }^{72}$ Teorijski razmatrajući, tada djelotvorno kajanje nije razlog za ublažavanje kazne nego za samo nepostojanje kazne. Upravo je u području kaznenih djela protiv okoliša u mnogim slučajevima poželjno preporučiti djelotvorno kajanje kako bi se smanjio rizik kaznene osude. Tada bi za odnos počinitelja i žrtve bio primaran samo građanski postupak.

Ako se počinitelj sam prijavi nadležnim službama s namjerom da otkloni prouzročeno stanje prije materijalnog dovršenja, tada se može priznati djelotvorno

${ }^{66} \mathrm{http}: / / w w w . j u s 24 . a t / a /$ rechtsfolge-der-t\%C3\%A4tigen-reue, preuzeto 10. rujna 2015.

${ }^{67}$ Hefendehl, op. cit., str. 461.

68 Novoselec, Opći dio ..., op. cit., str. 314.

69 Hefendehl, op. cit., str. 461.

$70 \mathrm{http}: / /$ www.jus24.at/a/rechtsfolge-der-t\%C3\%A4tigen-reue , preuzeto 10. rujna 2015.

71 Ibid.; Neki u pravu Švicarske smatraju kako je dovoljno poduzeti radnju, a kajanje nije potrebno pokazati. Ali postoje različita stajališta jer oni koji ne djeluju zbog svojih pobuda (aus eigenem Antrieb) ne ostvaruju zakonsku definiciju koja zahtijeva da počinitelj djeluje dobrovoljno. To će biti slučaj ako počinitelj djeluje pod pritiskom treće osobe. Ne postoji dobrovoljnost kad je počinitelj na temelju procjene trošak-korist odustao od počinjenja djela. Stratenwerth, prema: Kottmann, op. cit., str. 4.

72 Potrebno je vidjeti sastoji li se djelotvorno kajanje u sprečavanju materijalnog dovršenja ili u pokušaju sprečavanja materijalnog dovršenja. Kod kaznenih djela protiv okoliša potrebno je sprečavanje materijalnog dovršenja. 
kajanje iako je nadležno tijelo već znalo za počinjeno djelo. Tada počinitelj ne zna da je nadležno tijelo već upoznato s podatkom tko je počinitelj ${ }^{73}$ pa je ispunjen kriterij dobrovoljnosti. Treba priznati djelotvorno kajanje i u slučaju kada je počinitelj namjeravao ukloniti posljedice ali nije uspio pa je to u njegovo ime učinio treći prije nego je za to saznalo nadležno tijelo. ${ }^{74}$

Djelotvorno je kajanje strogo osobna okolnost i ne može se priznati onome koji nije osobno poduzeo radnju sprečavanja dovršenja kaznenog djela. Ako više osoba sudjeluje u počinjenju kaznenog djela, djelotvorno kajanje se priznaje samo onom tko ga je poduzeo a ne uračunava se ostalima. ${ }^{75}$ Drugačija je situacija ako kazneno djelo ne bi moglo biti formalno dovršeno bez djelovanja supočinitelja ${ }^{76}$ kada bi se radilo o dobrovoljnom odustanku.

Odredba o djelotvornom kajanju dolazi rijetko do primjene te stoga više predstavlja želju zakonodavca nego nekakvu praksu. Zakonodavac ovom odredbom nastoji staviti na znanje adresatima da mu je važnija zaštita nekog pravnog dobra nego kažnjavanje pojedinca. ${ }^{77}$ Stoga se može zaključiti da je za djelotvorno kajanje potrebno prouzročenje uzročnog niza koji ima za posljedicu sprečavanje materijalnog dovršenja. ${ }^{78}$

Za djelotvorno kajanje nije dostatno samo nečinjenje nakon formalnog dovršenja. Potrebno je da počinitelj sam spriječi nastupanje posljedice ili u sprečavanju posljedice sudjeluje. ${ }^{79} \mathrm{Ne}$ uspije li, ostaje neograničeno kažnjiv. ${ }^{80}$ Cinjenica neuspjeha u sprečavanju materijalnog dovršenja može igrati ulogu pri odmjeravanju kazne kao olakotna okolnost. Ovdje se ne može priznati nekauzalni odustanak prema čl. 35., st. 2. KZ-a jer on zahtijeva da je djelo ostalo u pokušaju.

\section{POREDBENO ZAKONODAVSTVO}

\subsection{Austrija}

U hrvatskoj literaturi uočava se razlikovanje dobrovoljnog odustanka od djelotvornog kajanja. Dobrovoljni je odustanak moguć samo dok je djelo još u pokušaju. Ako je, naprotiv, počinitelj već dovršio kazneno djelo, moguća je samo primjena instituta djelotvornog kajanja, koji dolazi u obzir u slučajevima izričito propisanima u Posebnom dijelu KZ-a. Dakle, očita je jasna vremenska razlika između ovih dvaju instituta, a ista je situacija i u pravu Austrije.

\footnotetext{
73 http://www.jus24.at/a/rechtsfolge-der-t\%C3\%A4tigen-reue, preuzeto 10. rujna 2015.

74 Ibid.

75 Kottmann, op. cit., str. 6.

$76 \mathrm{http}: / / w w w . r e c h t s l e x i k o n . n e t / d / t a e t i g e-r e u e / t a e t i g e-r e u e . h t m$, preuzeto 10. rujna 2015.

77 Busch - Iburg, op. cit., str. 33.

78 Kottmann, op. cit., str. 4.

79 Trechsel - Noll, Stratenwerth, prema: Ibid., str. 5.

80 Ibid.
} 
Dužnost suca u Austriji je, jednako kao i u njemačkom pravu, samo utvrditi ispunjenost zakonskih pretpostavki dobrovoljnog odustanka nakon čega je nekažnjavanje obvezno ${ }^{81}$ Relativna nerazvijenost austrijske dogmatike u ovom području može se vidjeti i iz nepostojanja detaljnih rasprava o teoretskom utemeljenju privilegiranja dobrovoljnog odustanka. Njegovo jednoglasno tretiranje kao osobnog razloga ukidanja kazne (persönlicher Strafaufhebungsgrund), bez kritičkog preispitivanja takve ocjene, dovodi do toga da se na dogmatskom polju ne može ocrtati kvalitativna razlika između dobrovoljnog odustanka i djelotvornog kajanja. ${ }^{82}$ Stoga se djelotvorno kajanje (tätige Reue), po svojoj pravnoj prirodi, pretežito izjednačuje s dobrovoljnim odustankom. Usprkos tome, kako je spomenuto, u austrijskoj kaznenopravnoj dogmatici vladajuće je mišljenje da su u pitanju dva samostalna $i$ međusobno neovisna pravna instituta ${ }^{83}$ jer između dobrovoljnog odustanka i djelotvornog kajanja postoji jasno vremensko razgraničenje, ali i kvalitativno vrednovanje. ${ }^{84}$

Zakonodavstvo Austrije ne kažnjava počinitelja koji poduzme radnju djelotvornog kajanja prema $\S 183$ b StGB za kaznena djela protiv okoliša ${ }^{85}$ Potrebno je da počinitelj pravovremeno i dobrovoljno posredstvom drugoga ili sam u cijelosti popravi štetu. Dovoljno je da pravovremeno sa žrtvom zaključi ugovor o naknadi štete prije nego je nadležno tijelo saznalo za formalno dovršenje kaznenog djela. Pravovremenost postoji ako počinitelj otkloni opasnost ili slična pogoršanja sve dok nije došlo do oštećenja ljudi, životinja ili biljnog svijeta. Mogućnost dobrovoljnog odustanka postoji sve dok stadij pokušaja nije prijeđen, ${ }^{86}$ a oštećenje ljudi, životinja ili biljnog svijeta predstavlja materijalno dovršenje. Ratio je ugovora o naknadi štete u tome da se počinitelju pomogne da popravi štetu koju je prouzročio. Stoga je nedopuštena primjena djelotvornog kajanja na pokušaj. ${ }^{87} \mathrm{~S}$ obzirom na to da dobrovoljni odustanak nije moguć kod pripremnih radnji koje su predviđene kao dovršeno kazneno djelo, zakonodavac predviđa djelotvorno kajanje ${ }^{88}$ kod pripremnih radnji koje su u StGB-u predviđene

81 Vuletić, op. cit., str. 112.

82 Ibid., 115 .

83 Ibid.

84 Kienapfel/Höpfel, prema: Brockhaus, M., Die strafrechtliche Dogmatik von Vorbereitung, Versuch und Rücktritt im europäischen Vergleich: unter Einbeziehung der aktuellen Entwicklungen zur “Europäisierung” des Strafrechts, Hamburg, 2006., str. 265.

85 Uzimajući u obzir djelotvorno kajanje koje je predviđeno kod mnoštva kaznenih djela u austrijskom StGB-u, a što se kritizira, u svim paragrafima je kao pravni učinak predviđeno obvezno nekažnjavanje počinitelja (\$165a, 167, 226, 240, 241d, 241g, $243 \mathrm{i}$ dr.).

86 „Wegen einer der in den $\oint \oint 180,181$ und $181 \mathrm{~b}$ bis 183 mit Strafe bedrohten Handlungen ist nicht zu bestrafen, wer freiwillig und bevor die Behörde (\$151 Abs. 3) von seinem Verschulden erfahren hat, die von ihm herbeigeführten Gefahren, Verunreinigungen und sonstigen Beeinträchtigungen beseitigt, sofern es nicht schon zu einer Schädigung eines Menschen oder des Tier-oder Pflanzenbestandes gekommen ist. " Brockhaus, op. cit., str. 266.

87 Ibid.

88 Ibid., str. 267. 
kao kazneno djelo jer je to jedini mogući instrument anuliranja negativnih učinaka formalno dovršenog kaznenog djela.

Austrijski je zakonodavac značajno povećao broj kaznenih djela kod kojih djelotvorno kajanje može voditi do nekažnjivosti te teoretičari takvo što nazivaju relativiziranjem. Ipak, takvom se odredbom stimulira odmicanje počinitelja od kaznenog djela i nakon što je kazneno djelo formalno dovršeno. ${ }^{89}$ Ratio legis ove odluke zakonodavca jest što time hoće stvoriti poticaj za otklanjanje posljedica nakon dovršenja djela te tako priskrbiti žrtvi brzo i učinkovito uklanjanje štete.

\subsection{SR Njemačka}

Zakonodavstvo SR Njemačke za djelotvorno kajanje kod kaznenih djela konkretnog ugrožavanja zahtijeva preveniranje opasnosti (Gefahr abwenden) prije nastupa znatne štete dok kod kaznenih djela apstraktne opasnosti zahtijeva eliminiranje prouzročenog stanja (Zustand beseitigen). Eliminiranje stvorenih okolnosti podobnih za izazivanje opasnosti može se izvršiti i naknadno samostalno ili putem nadležnih tijela. ${ }^{90}$ Za djelotvorno kajanje kod kaznenih djela protiv okoliša predviđeno je fakultativno ublažavanje kazne ili fakultativno oslobođenje od kazne ako počinitelj otkloni opasnost prije nego nastupi znatna šteta prema § 330b StGB-a. ${ }^{91}$ Znatna šteta na stvari predstavlja materijalno dovršenje, a postoji ako je stvar pretrpjela značajan gubitak vrijednosti. Ako su nastali neki posredni troškovi, kao što je potreba za čišćenjem stvari ili popravcima koji se ne reflektiraju na vrijednost stvari, tada nije nastupila znatna šteta i postoji mogućnost primjene djelotvornog kajanja i na te slučajeve. ${ }^{92}$ Ista je situacija i ako je, pored apstraktne, nastupila i konkretna opasnost. Sprečavanje opasnosti kao radnja djelotvornog kajanja mora biti uzrok nenastupanju znatne štete da bi postojali pravni učinci djelotvornog kajanja. Ako je radnja djelotvornog kajanja prouzročila daljnju štetu, takvu okolnost treba uzeti u obzir pri odmjeravanju kazne u sudskom postupku. ${ }^{93}$ Ako počinitelj poduzme radnju djelotvornog kajanja dobrovoljno i s naporom, a

89 Ibid., str. 265.

90 Cramer, u: Schönke, A. - Schröder, H., StBG Kommentar, München, 1997., str. 2248.

91 „,(1) Das Gericht kann in den Fällen des $\S 325 a$ Abs. 2, des $\S 326$ Abs. 1 bis 3, des $\S 328$ Abs. 1 bis 3 und des $\$ 330 a$ Abs. 1, 3 und 4 die Strafe nach seinem Ermessen mildern (\$ 49 Abs. 2) oder von Strafe nach diesen Vorschriften absehen, wenn der Täter freiwillig die Gefahr abwendet oder den von ihm verursachten Zustand beseitigt, bevor ein erheblicher Schaden entsteht. Unter denselben Voraussetzungen wird der Täter nicht nach § $325 a$ Abs. 3 Nr. 2, § 326 Abs. 5, § 328 Abs. 5 und § 330a Abs. 5 bestraft.

(2) Wird ohne Zutun des Täters die Gefahr abgewendet oder der rechtswidrig verursachte Zustand beseitigt, so genügt sein freiwilliges und ernsthaftes Bemühen, dieses Ziel zu erreichen. " U njemačkom StGB-u (\$ 314a. st. 3, 320. st. 3., 306e st. 2.) predviđena je mogućnost ublažavanja kazne, oslobođenja od kazne ili u nekim slučajevima čak obvezno oslobođenje od kazne za radnju djelotvornog kajanja.

92 Cramer, u: Schönke - Schröder, op. cit., str. 2248.

93 Kühl, K. - Lackner, K., StGB Kommentar, München, 2007., str. 1460; Tröndle, H. - Fischer, T., StGB und Nebengesetze, München, 1999., str. 1806-1807. 
Dr. sc. Ivan Vukušić: „Odustanak“ kod posebnih kaznenih djela ugrožavanja okoliša Zbornik radova Pravnog fakulteta u Splitu, god. 53, 2/2016., str. 581.-600.

ne dođe do materijalnog dovršenja neovisno o njegovoj radnji, tada je moguće priznati djelotvorno kajanje prema $\S 330 \mathrm{~b}$ st. 2 . StGB-a. ${ }^{94}$

\subsection{Francuska}

Francuska teorija razlikuje dobrovoljni odustanak od djelotvornog kajanja (repentir actif). Navodi se da odustanak više nije moguć nakon dovršenja kaznenog djela. ${ }^{95}$ Tada je, međutim, moguće djelotvorno kajanje koje mora biti usmjereno na umanjenje ili, ako je moguće, uklanjanje posljedica počinjenog djela. Ove dvije pravne figure ni na koji se način vremenski ne preklapaju. ${ }^{96}$ Temeljna je razlika među njima u tome što dobrovoljni odustanak oduzima pokušaju deliktni karakter, dok kod djelotvornog kajanja taj karakter ostaje netaknut i djelo ostaje kažnjivo. Djelotvorno kajanje stoga djeluje ex post $t^{97}$ te omogućava da se počinitelju prije materijalnog dovršenja ne zatvori put povratka u pravni sustav..$^{98}$

Djelotvorno kajanje ne vodi do obveznog oslobođenja od kazne. Ono je moguće samo ako ga zakonodavac predvidi kod konkretnog kaznenog djela. ${ }^{99}$

Neki autori smatraju da bi djelotvornom kajanju trebalo pripisati značajnije pravne učinke. Tako primjerice Pradel navodi da je postojeće rješenje nepravedno jer djelotvorno kajanje zahtijeva puno veći trud nego dobrovoljni odustanak. Kradljivac koji vraća stvar koju je ranije oduzeo izlaže se većoj opasnosti od kradljivca koji samo odlazi iz prostora u koji je provalio, a da pritom nije ništa uzeo. On smatra da djelotvorno kajanje zaslužuje barem oslobođenje od

94 Cramer, u: Schönke - Schröder, op. cit., str. 2248. Njemački StGB poznaje u Općem dijelu odredbu o nekauzalnom odustanku, ali ta se odredba primjenjuje kada je djelo ostalo u stadiju pokušaja. Ako se uzme u obzir kako kod kaznenih djela protiv okoliša ugrožavanje istodobno predstavlja pripremnu radnju, pokušaj i dovršenje kaznenog djela, za pokušaj anuliranja takvih negativnih posljedica potrebno je propisati posebnu odredbu u Posebnom dijelu KZ-a koju možemo nazvati nekauzalnim djelotvornim kajanjem.

95 Brockhaus, op. cit., str. 121.

96 Ibid.

97 Stefani-Levasseur-Bouloc, Pradel, prema: Vuletić, op. cit., str. 126.

98 Pradel, prema: Ibid., str. 125.

99 Brockhaus, op. cit., str. 121.; Prema čl. 450-2 Code Penala (CP), sudionik kriminalnog udruženja ostaje nekažnjen ako otkrije kriminalno udruženje nadležnim tijelima. Ova je pretpostavka ispunjena ako se otkrije identitet ostalih sudionika tako da postoji mogućnost njihove identifikacije. Za razliku od dobrovoljnog odustanka koji podrazumijeva dobrovoljnu radnju, dobrovoljna radnja nije potrebna jer se dobrovoljnost očituje u podacima koji su dani nadležnim tijelima. Čl. 450-2 predstavlja zakonski ispričavajući razlog koji ne odgovara ispričavajućem razlogu u hrvatskom pravu te se ovaj pojam francuskog prava može izjednačiti s osobnim razlogom ukidanja kazne. Francuski CP predviđa ublažavanje kazne za polovicu kod djelotvornog kajanja u slučaju kaznenog djela krivotvorenja novca i vrijednosnih papira (čl. 442-10) i kod zlouporabe opojnih droga u smislu prodaje i stavljanja na raspolaganje (čl. 222-43). Potrebno je da počinitelj otkrivanjem podataka administrativnom ili sudskom tijelu omogući otkrivanje drugih počinitelja ili omogući nedovršenje kaznene djelatnosti. Marpol konvencija o zaštiti okoliša predviđa djelotvorno kajanje kod kaznenih djela protiv okoliša što je francuski parlament odbio usvojiti u Zakonu o zaštiti okoliša.

O različitom shvaćanju oblika krivnje i kritiku takvog rješenja v. https://www.courdecassation.fr/ venements_23/colloques_formations_4/2005_2033/andre_huet_8126.html, preuzeto 21.rujna 2015. 
kazne jer se „onaj koji se djelotvorno kaje trudi izbrisati negativne posljedice svog prvobitnog čina, dok se onaj koji odustaje samo povlači iz realizacije svog prvobitnog plana“. ${ }^{100}$ Treba primijetiti da Pradelovo stajalište sigurno proizlazi iz nerazlikovanja nedovršenog od dovršenog pokušaja. Naime, on očito gubi iz vida da počinitelj koji dobrovoljno odustaje ponekad mora poduzeti aktivnu radnju kojom će spriječiti nastup posljedice. Na taj se način on izlaže znatnoj opasnosti od otkrivanja i njegovo djelovanje je kriminalnopolitički vrednije od djelotvornog kajanja jer on omogućuje da djelo ostane u pokušaju. Kod djelotvornog kajanja, naprotiv, to više nije moguće i povreda pravnog dobra je bespovratno nastupila. ${ }^{101}$

\section{9. „ODUSTANAK“ PREMA HRVATSKOM KAZNENOM PRAVU}

Hrvatski je zakonodavac propisao fakultativno oslobođenje od kazne za dobrovoljni odustanak, ali i za djelotvorno kajanje. Međutim upitna je opravdanost takvog izjednačavanja.

Fakultativno oslobođenje od kazne kod djelotvornog kajanja predviđeno je, primjerice, i za počinitelja otmice, terorističkog udruženja, zločinačkog udruženja, za protupravno oduzimanje slobode. ${ }^{102} \mathrm{~S}$ obzirom na to da je pravni učinak djelotvornog kajanja jednak pravnom učinku dobrovoljnog odustanka, u teoriji čak postoje prijedlozi da se ta dva instituta tretiraju podvarijantama jednog zajedničkog šireg pojma.

Unatoč tome što bi se razmatranje ovih dvaju instituta u okviru jedinstvenog, šireg pojma možda i moglo tolerirati u svrhu sistematičnog prikazivanja, ne treba izgubiti iz vida da među njima postoji vrlo značajna suštinska razlika. Ona se sastoji u tome da kod djelotvornog kajanja počinitelj samo pokušava ublažiti već prouzročenu štetu. Za razliku od toga, kod dobrovoljnog odustanka djelo je još uvijek u pokušaju pa je i počinjena šteta znatno manja, osobito ako se radi o nedovršenom pokušaju. S obzirom na tu nepobitnu činjenicu, zakonsko izjednačavanje ovih dvaju instituta po pitanju pravnog učinka ne može nikako biti opravdano $^{103}$ jer, po prirodi stvari, nije moguće da djelotvorno kajanje u sebi sadrži značajnije smanjenje neprava i krivnje od situacija dobrovoljnog odustanka. S druge strane, ako se takav učinak opravdava lakšim dokazivanjem težih kaznenih djela, tada se radi o miješanju materijalnopravnih i procesnopravnih kategorija. Nije opravdano koristiti institute kaznenog materijalnog prava da bi se udovoljilo ciljevima lakšeg dokazivanja u kaznenom postupku ako to istodobno znači da se mora odstupiti od temeljnih načela kaznenog materijalnog prava. ${ }^{104}$

100 Pradel, prema: Vuletić, op. cit., str. 127.

101 Ibid.

102 Kurtović Mišić - Krstulović Dragičević, op. cit., str. 154.

103 Vuletić, op. cit., str. 233.; KZ/07 je djelotvornom kajanju u nekim slučajevima propisao jači pravni učinak nego dobrovoljnom odustanku.

104 Ibid. 


\section{ZAKLJUČAK}

Prelaskom na dominantno ekocentrični model kaznenih djela protiv okoliša kod kojih je uglavnom dovoljno već nehajno apstraktno ugrožavanje da bi se radilo o kaznenom djelu, valja izbjeći izricanje kazne gdje god nema posebne potrebe za kaznom i gdje je to korisno za okoliš. Iz tog razloga hrvatski zakonodavac opravdano otvara mogućnost djelotvornog kajanja kod kaznenih djela protiv okoliša.

Navedeni razlozi u radu jasno ukazuju kako je kod dobrovoljnog odustanka smanjenje neprava i krivnje osjetno veće nego kod djelotvornog kajanja pa je jedino logično rješenje da se dobrovoljnom odustanku priznaju značajniji pravni učinci nego djelotvornom kajanju. ${ }^{105}$ Stoviše, u onim situacijama u kojima sud samo blaže kažnjava dobrovoljni odustanak i djelotvorno kajanje, posve se gubi razlika spram instituta pokušaja kaznenog djela iz čl. 34. KZ-a pa čitava koncepcija dobrovoljnog odustanka zapravo gubi smisao.

Kod djelotvornog kajanja radi se, doduše, o počinitelju koji je promijenio svoj prvotni stav, ali tu je kazneno djelo formalno dovršeno i počinitelj jedino može eventualno ublažiti njegove posljedice. Ovdje počinitelj ne može više spriječiti povredu zaštićenog pravnog dobra, za razliku od dobrovoljnog odustanka. Stoga bi sud, unatoč istim pravnim učincima, trebao pokloniti više pozornosti načinu odmjeravanja kazne što će, naravno, ovisiti i o konkretnom činjeničnom stanju, kada propisani isti pravni učinci ne bi stvarali veći problem.

Iako je na prvi pogled izjednačen pravni učinak dobrovoljnog odustanka i djelotvornog kajanja, ne smije se zanemariti da fakultativno oslobođenje od kazne omogućava kažnjavanje kao za dovršeno kazneno djelo, neograničeno ublažavanje kazne, a naposljetku i oslobođenje od kazne. Stoga zakonodavac RH koristi bolji pravni izraz za pravne učinke djelotvornog kajanja od zakonodavca SR Njemačke. U njemačkom StGB-u se kod djelotvornog kajanja uz kaznena djela pojedinačno nabrajaju ove mogućnosti. Opravdanost nabrajanja ovih pravnih učinaka može proizaći jedino kada StGB SR Njemačke uz različite oblike počinjenja istog kaznenog djela vezuje različite pravne učinke djelotvornog kajanja. Ipak, i tada se radi o nepotrebnom opterećenju zakonskog teksta.

Nije opravdano ni rješenje StGB-a Austrije prema kojem se počinitelj koji je poduzeo radnju djelotvornog kajanja obvezno ne kažnjava. Time se onemogućava sudu da procijeni sve okolnosti počinjenja kaznenog djela (oblik krivnje s kojim je kazneno djelo formalno dovršeno, pobude, način počinjenja) i u skladu s konkretnim činjeničnim stanjem odredi sankcije za počinitelja.

U poredbenom se zakonodavstvu pak nalazi pohvalna odredba koja predviđa okolnost „nekauzalnog djelotvornog kajanja“ nakon formalnog dovršenja kaznenog djela. Stoga bi zakonodavac RH trebao propisati djelotvorno kajanje i kada se počinitelj dobrovoljno i s naporom trudio da ne dođe do materijalnog dovršenja (odnosno da se trudio otkloniti opasnost kod kaznenih djela protiv

105 Ibid., str. 234. 
okoliša), a do materijalnog dovršenja ne dođe neovisno o njegovoj radnji. Ovakva je mogućnost minimalan ustupak počinitelju ako se uzme u obzir da zakonodavac kod kaznenih djela terorističkog udruženja i zločinačkog udruženja predviđa primjenu djelotvornog kajanja čak i kada je došlo do materijalnog dovršenja kaznenog djela, a počinitelj je otkrio podatke o postojanju udruženja nadležnim tijelima. „Nekauzalno djelotvorno kajanje“ se uistinu može uzeti u obzir kao olakotna okolnost, ali je li to uvijek prikladno kada kazneno djelo ne bude materijalno dovršeno a počinitelj se iskreno i s naporom trudio da ne dođe do materijalnog dovršenja?

Postavlja se i pitanje nepropisivanja djelotvornog kajanja za kazneno djelo ugrožavanja ozonskog sloja. Toje vjerojatno iz razloga što zakonodavac materijalno dovršenje promatra kroz čl. 214. KZ-a, odnosno nastup teških posljedica za okolišs. Činjenica je da, unatoč današnjoj tehnologiji, nije jednostavno sudu uz pomoć sudskih vještaka odrediti koja radnja u kojoj mjeri oštećuje ozonski sloj. ${ }^{106}$ Slična situacija je i s kaznenim djelom ugrožavanja bukom, vibracijama ili neionizirajućim zračenjem. Ako se materijalno dovršenje za kaznena djela ugrožavanja okoliša promatra kroz teške posljedice sukladno čl. 213. KZ-a, tada djelotvorno kajanje treba omogućiti i kod ovog kaznenog djela jer su teške posljedice ovog kaznenog djela, odnosno materijalno dovršenje, kažnjive čl. 214. KZ-a.

\title{
“ABANDONMENT" IN CERTAIN CRIMINAL ACTS OF ENDANGERING THE ENVIRONMENT
}

\begin{abstract}
"Abandonment" in certain criminal acts of endangering the environment is analysed in this paper. Given the specificity and problem areas arising in prescribing culpability in compromising legal good, the legislator in RH has provided the opportunity for effective contrition for certain criminal acts against the environment. Therefore, the forms of "abandonment" are analysed which, pursuant to the current Criminal Act include, voluntary abandonment and effective contrition. "Non-clausal effective contrition" should also be included.
\end{abstract}

Key word: environment, protection of environment, criminal acts against environment

106 Možda zakonodavac smatra da ne postoji mogućnost povratka na put prava odnosno poduzimanja radnje kojom se obnavlja ozonski sloj. Tada bi pak svakako trebalo brisati pojam ugrožavanja iz naziva spomenutog kaznenog djela. Kako zakonodavac u čl. 214. KZ-a nije predvidio materijalno dovršenje za ovo kazneno djelo, proizlazi da teže posljedice nisu moguće. 